\title{
Biological effect monitoring of occupational exposure to 1,3-dichloropropene: effects on liver and renal function and on glutathione conjugation
}

\author{
E J Brouwer, C T A Evelo, A J W Verplanke, R T H van Welie, F A de Wolff
}

\begin{abstract}
A prospective study was performed in the Dutch flower bulb culture to investigate the possible effects of subchronic exposure to the soil fumigant 1,3-dichloropropene (DCP) on liver and kidney function and on glutathione conjugation capacity in blood. Urine spot samples and venous blood samples from 14 workers applying DCP (applicators) were taken at the start of the season in July, and after the season in October. The parameters of liver function measured were: alanine aminotransferase, aspartate aminotransferase, alkaline phosphatase, lactate dehydrogenase, $\gamma$-glutamyltranspeptidase, and total bilirubin (conjugated and unconjugated). Total bilirubin was significantly decreased from 9.5 before to $7 \cdot 0 \mu \mathrm{mol} / 1$ after the season. In combination with an increase in serum $\gamma$-glutamyltranspeptidase activity from 12.5 to $19.5 \mathrm{U} / 1$ this indicates moderate hepatic enzyme induction. To study renal function, creatinine and $\beta_{2}-$ microglobulin in serum, and $\beta_{2}$-microglobulin, albumin, alanine aminopeptidase, $\beta$-galactosidase, and retinol binding protein in urine were measured. The glomerular func-
\end{abstract}

Toxicology Laboratory, University Hospital, Building 1, L1-P, PO Box 9600, 2300 RC Leiden, The Netherlands

E J Brouwer, F A de Wolff

Department of Toxicology, Faculty of Medicine, University of Nijmegen, The Netherlands. Present address: Department of Occupational and Environmental Health and Toxicology, University of Limburg, The Netherlands

C T A Evelo

Coronel Laboratory for Occupational and Environmental Health, University of Amsterdam, The Netherlands

A J W Verplanke

Department of Pharmacochemistry, Division of Molecular Toxicology, Free University, Amsterdam, The Netherlands

$\mathrm{R} T \mathrm{H}$ van Welie tion parameters albumin in urine and creatinine in serum changed significantly during the season: albumin concentration increased from 5.2 to $7.6 \mathrm{mg} / 1$, whereas creatinine excretion decreased from 93.0 to $87.5 \mu \mathrm{mol} / 1$. The tubular function parameter retinol binding protein also increased in concentration from 20.0 to $26.9 \mu \mathrm{g} / 1$. Therefore, a subclinical nephrotoxic effect of subchronic exposure to DCP cannot be excluded. Effects on glutathione conjugation capacity were studied by measuring erythrocyte glutathione S-transferase activity and blood glutathione concentrations. The activity of glutathione S-transferase in erythrocytes was significantly decreased from $4 \cdot 7$ before to $3.3 \mathrm{U} / \mathrm{g}$ haemoglobin after the season. The same was true for the blood glutathione concentrations, which decreased from 0.93 to $0.82 \mathrm{mM}$. Both parameters seem to be affected by exposure to DCP.

A mixture of Z- and E-1,3-dichloropropene (DCP) is used extensively in the Dutch flower bulb culture for soil fumigation. This is mainly performed by commercial applicators. Products containing DCP, such as Telone II and Shell-DD 95, are injected into the soil, without previous dilution, in the period between June and November. During field application of soil fumigants containing DCP, applicators may be exposed to DCP, mainly by inhalation.

The primary target organs of DCP toxicity in experimental animals are the liver and the kidney. Exposure of rats and guinea pigs to $50 \mathrm{ppm}(220 \mathrm{mg}$ / $\left.\mathrm{m}^{3}\right)$ DCP vapour by inhalation for seven hours a day, five days a week during one month induced liver and kidney injury. Exposure to $3 \mathrm{ppm}\left(13.6 \mathrm{mg} / \mathrm{m}^{3}\right)$ for six months induced cloudy swelling of the renal tubular epithelium in male rats. This was found to be reversible after stopping exposure. ${ }^{1}$ Based on evidence of no effects in rats, mice, guinea pigs, and dogs exposed seven hours a day to $1 \mathrm{ppm}\left(4.5 \mathrm{mg} / \mathrm{m}^{3}\right)$ for six months, and of the reversible injury in male rats exposed to $3 \mathrm{ppm}$, a time weighted average 
threshold limit value (TLV) of $1 \mathrm{ppm}$ has been recommended for dichloropropene. ${ }^{2}$ This is also the present Dutch occupational exposure limit (OEL). ${ }^{3}$

Apart from a recent study about short term exposure to DCP and renal effects, ${ }^{4}$ no studies of exposure to DCP on health effects in man have been published.

In combination with an environmental and biological monitoring study of DCP in the Dutch flower bulb culture ${ }^{56}$ the present prospective exploratory study was carried out to investigate the early effects of subchronic exposure to DCP on liver and renal function of commercial applicators.

Exposure to electrophilic compounds such as DCP or its metabolites might lead to a loss of biologically active thiol groups and assessment of this loss could be useful as a biological marker of exposure. ${ }^{7}$ In this study two parameters of change in thiol groupsnamely, erythrocyte glutathione S-transferase activity and blood glutathione concentration-were also evaluated.

\section{Methods}

\section{POPULATION AND STUDY DESIGN}

The study was restricted to the "Bollenstreek," the area between Leiden and Haarlem (The Netherlands) where the flower bulb culture is mainly concentrated. All fourteen commercial applicators using DCP in soil fumigation in this region participated in the study, which was approved by the medical ethics committee of the University Hospital of Leiden.

By means of a questionnaire, completed in July on the first sampling day, information was obtained from each subject on age, smoking and drinking habits, medication, and current and past diseases. The mean age was 42 years (median 40, range 33-60). Five workers smoked, with an average rate of 15-20 cigarettes a day (range 1-5 to $>20$ ). The average alcohol intake was 5-10 glasses a week (range $<1$ to $>60$ ). One applicator did not drink alcoholic beverages. Two applicators used an oral anticoagulant (phenprocoumon). None of the workers was known to have liver or kidney disease.

For 12 applicators blood and urine samples were collected between 12.00 am and $2.00 \mathrm{pm}$ both before and after the season; for two, samples were collected between 6.00 and $7.00 \mathrm{pm}$ before and after the season.

Possible effects of exposure to DCP on the liver were studied by measuring alanine aminotransferase (ALAT), aspartate aminotransferase (ASAT), lactate dehydrogenase (SLDH), $\gamma$-glutamyltranspeptidase (GGT), and alkaline phosphatase (ALP) activities, and total bilirubin concentrations (Bil-tot) in serum. To study effects on renal function, parameters were chosen to discriminate between effects on glomerular and tubular function.
Glomerular function was measured by assessing concentrations of $\beta_{2}$-microglobulin in serum $\left(\beta_{2}-M-S\right)$, creatinine in serum (Creat-S), and albumin in urine (Alb-U). Proximal tubular function was reflected by the excretion of $\beta_{2}$-microglobulin $\left(\beta_{2}-\mathrm{M}-\mathrm{U}\right)$, retinol binding protein (RBP), $\beta$-galactosidase $(\beta-\mathrm{Gal})$, and alanine aminopeptidase (AAP) in urine. Effects on glutathione conjugation capacity in blood were evaluated by measuring blood glutathione (GSH) concentrations and the activity of erythrocyte glutathione S-transferase (GST: EC 2.5.1.18).

\section{ANALYTICAL METHODS}

Blood samples for measurement of liver and renal function parameters were collected by venepuncture using $10 \mathrm{ml}$ Vacutainer tubes. Blood was allowed to clot and transported within two hours in a cool box to the Laboratories for Clinical Chemistry and Toxicology, University Hospital of Leiden. For the determination of GST activities and GSH concentrations blood samples were collected in $10 \mathrm{ml}$ Vacutainer tubes containing ethylenediaminetetraacetic acid (EDTA).

The samples for the determination of ALAT, ASAT, SLDH, GGT, and ALP activities and, Biltot and Creat-S concentrations in serum were analysed within 24 hours with a SMAC multichannel analyser (Technicon Instruments Corporation, Tarrytown, NY, USA) according to the manufacturer's instructions. Concentrations of the protein $\beta_{2}-M$ in urine and serum were measured with a commercial radioimmunoassay kit (Pharmacia Diagnostics AB, Uppsala, Sweden).

For the determination of Alb-U and RBP concentrations and $\beta-\mathrm{Gal}$ and AAP activities, the urine samples were cooled and transported on ice to the Coronel Laboratory, University of Amsterdam, prepared the same day, and analysed within one week. Concentrations of Alb-U and RBP were analysed with a latex immunoassay according to Bernard and Lauwerys. ${ }^{8}$ For the determination of $\beta$ Gal activity, a colorimetric assay according to Maru$\mathrm{hn}^{9}$ was used. Alanine aminopeptidase activity was assayed by the method of Jung and Scholz. ${ }^{10}$ In earlier studies reported from the Coronel Laboratory coefficients of variation were: Alb-U 3\%, RBP 10\%, and $\beta-\mathrm{Gal} 5 \% .{ }^{11}$ Assuming thąt the ratio between the renal function parameters and the urinary density was the same before and after the season the data were adjusted for urinary density. ${ }^{11}$

Blood samples used for GST and GSH determinations were transported in a cool box to the Department of Toxicology, University of Nijmegen, and prepared (GST) or analysed (GSH) the same day. Concentration of GSH was determined essentially as described by Anderson. ${ }^{12}$ For the determination of GST activity in erythrocytes, red cells were washed 
three times with phosphate buffered saline (PBS; $\mathrm{pH}$ $7 \cdot 0)$ and lysed by addition of three volumes of water containing $1.4 \mathrm{mM}$ neutral dithiothreitol (DTT) to prevent oxidation of thiol groups. After the ionic strength had been restored by adding one volume twofold concentrated PBS containing 1.4 mM DTT, cell fragments were removed by centrifugation at $15000 \mathrm{~g}$ for 10 minutes. Only the clear upper part of the supernatant was used for the determinations. The activity towards 1-chloro-2,4-dinitrobenzene (CDNB) was determined as described by Habig and Jacoby ${ }^{13}$ with a Cary 118 spectrophotometer in auto slit mode with the gain adjusted to $2 \cdot 5$.

The concentration of haemoglobin $(\mathrm{Hb})$ in the haemolysates was determined with the haemoglobin cyanide procedure. ${ }^{14}$

\section{EXPOSURE}

After the season all applicators were asked to estimate the number of hours and days worked in soil fumigation.

\section{STATISTICAL ANALYSES}

To test for significance of differences between values for liver and renal function parameters and blood GST and GSH values measured before and after the season, matched pair analysis was performed with the Wilcoxon non-parametric signed rank test. For $\beta$ Gal at $\mathrm{pH}>7.0$ (five samples) and for $\beta_{2}-\mathrm{M}-\mathrm{U}$ at $\mathrm{pH}<5.5$ (eight samples) data were excluded from the analysis because of instability above or below these $\mathrm{pH}$ values. ${ }^{11}$ Data were analysed both with and without adjustment for urinary density.

The Friedman test was used to test for equality between values before and after the season for the liver parameters, and the glomerular and tubular function parameters simultaneously. All statistical analyses were performed with the statistical package of the social sciences SPSS $(-\mathrm{X}) .^{15}$

Table 1 Liver function parameters before and after the season: values corrected for specific density $(n=14)$

\begin{tabular}{|c|c|c|c|}
\hline & $\begin{array}{l}\text { Before season } \\
\text { (median } \\
\text { (range)) }\end{array}$ & $\begin{array}{l}\text { After season } \\
\text { (median } \\
\text { (range)) }\end{array}$ & p Value \\
\hline $\begin{array}{l}\text { Bil-tot } \\
\text { ( } \mu \mathrm{mol} / 1 \text { ) } \\
\text { ALP } \\
\text { (U/1) } \\
\text { ASAT } \\
\text { (U/1) } \\
\text { ALAT } \\
\text { (U/1) } \\
\text { SLDH } \\
\text { (U/1) } \\
\text { GGT } \\
\text { (U/1) }\end{array}$ & $\begin{array}{c}9 \cdot 5 \\
(6 \cdot 0-15 \cdot 0) \\
38 \cdot 5 \\
(26 \cdot 0-69 \cdot 0) \\
8 \cdot 5 \\
(6 \cdot 0-11 \cdot 0) \\
10 \cdot 5 \\
(5 \cdot 0-20 \cdot 0) \\
145 \cdot 5 \\
(117 \cdot 0-189 \cdot 0) \\
12 \cdot 5 \\
(5 \cdot 0-31 \cdot 0)\end{array}$ & $\begin{array}{c}7 \cdot 0 \\
(1 \cdot 0-14 \cdot 0) \\
39 \cdot 5 \\
(26 \cdot 0-68 \cdot 0) \\
8 \cdot 0 \\
(5 \cdot 0-18 \cdot 0) \\
12 \cdot 0 \\
(6 \cdot 0-36 \cdot 0) \\
149 \cdot 0 \\
(119 \cdot 0-194 \cdot 0) \\
19 \cdot 5 \\
(9 \cdot 0-34 \cdot 0)\end{array}$ & $\begin{array}{l}0.025^{\star} \\
0.576 \\
0.155 \\
0.235 \\
0.972 \\
0.099\end{array}$ \\
\hline
\end{tabular}

^Statistically significant $(\mathrm{p}<0.05)$.
Table 2 Renal function parameters before and after the season. Values corrected for specific density ( $n=14$ unless stated otherwise)

\begin{tabular}{|c|c|c|c|}
\hline & $\begin{array}{l}\text { Before season } \\
\text { (median } \\
\text { (range)) }\end{array}$ & $\begin{array}{l}\text { After season } \\
\text { (median } \\
\text { (range)) }\end{array}$ & p Value \\
\hline $\begin{array}{l}\text { Creat-S } \\
(\mu \mathrm{mol} / \mathrm{l})\end{array}$ & $\begin{array}{l}93.0 \\
(74.0-109.0)\end{array}$ & $\begin{array}{l}87 \cdot 5 \\
(42 \cdot 0-100 \cdot 0)\end{array}$ & $0.045^{\star}$ \\
\hline & & & 0.563 \\
\hline $\begin{array}{l}\beta_{2}-M-U \\
(\mu \mathrm{g} / \mathrm{l})\end{array}$ & $\begin{array}{l}76 \cdot 4 \\
(45 \cdot 0-174 \cdot 3) \\
(n=8)\end{array}$ & $\begin{array}{l}109 \cdot 9 \\
(65 \cdot 3-350 \cdot 9) \\
(\mathbf{n}=12)\end{array}$ & 0.208 \\
\hline $\begin{array}{l}\text { AAP } \\
(\mathrm{U} / \mathbf{l})\end{array}$ & $\begin{array}{l}9.7 \\
(6.5-13.9) \\
(\mathrm{n}=12)\end{array}$ & $\begin{array}{c}8 \cdot 3 \\
(5 \cdot 0-18 \cdot 6) \\
(\mathbf{n}=13)\end{array}$ & 0.754 \\
\hline $\begin{array}{l}\beta-\mathrm{Gal} \\
(\mathrm{U} / \mathrm{I})\end{array}$ & $\begin{array}{l}1 \cdot 9 \\
(1 \cdot 1-7 \cdot 2) \\
(n=11)\end{array}$ & $\begin{array}{c}2 \cdot 4 \\
(1 \cdot 7-5 \cdot 6) \\
(\mathrm{n}=12)\end{array}$ & 0.308 \\
\hline Alb-U & $\begin{array}{l}5 \cdot 2 \\
(1.6-31 \cdot 8)\end{array}$ & $\begin{array}{l}7 \cdot 6 \\
(2 \cdot 7-37 \cdot 0)\end{array}$ & $0.013^{\star}$ \\
\hline $\begin{array}{l}\mathrm{RBP} \\
(\mu \mathrm{g} / \mathrm{l})\end{array}$ & $\begin{array}{l}20 \cdot 0 \\
(8 \cdot 4-36 \cdot 1)\end{array}$ & $\begin{array}{l}26 \cdot 9 \\
(16 \cdot 5-72 \cdot 7)\end{array}$ & $0.036^{\star}$ \\
\hline
\end{tabular}

*Statistically significant $(p<0.05)$.

\section{Results}

EXPOSURE

All 14 applicators took part in soil fumigation with DCP during the season. The total number of working hours for each subject during this period varied from 26 to 300 with a median of 142 hours, divided over four to 37 days with a median of 20 days.

The number of hours during which the applicators fumigate soil only indicates the duration and not the level of exposure. These exposure data are not used therefore, to calculate a dose response relation.

In the environmental monitoring study, ${ }^{5}$ exposure to DCP for each applicator was measured on one or two days for biological monitoring. ${ }^{6}$ These data cannot be considered representative of the average exposure of the different applicators during the season and are, therefore, not suitable for an estimation of subchronic exposure to DCP of the 14 workers in this study.

From the enviromental monitoring study it appeared that exposure was comparatively high. The TWA concentration of DCP ranged from 1.9 to $18.9 \mathrm{mg} / \mathrm{m}^{3}$. On $30 \%$ of the observed working days the Dutch occupational exposure limit of $5 \mathrm{mg} / \mathrm{m}^{3}$ (1 ppm) was exceeded. ${ }^{5}$

Table 3 Glutathione S-transferase activity (CDNB) in erythrocytes and glutathione concentration in blood before and after the season $(n=12)$

\begin{tabular}{llll}
\hline & $\begin{array}{l}\text { Before season } \\
\text { (median } \\
\text { (range) }\end{array}$ & $\begin{array}{l}\text { After season } \\
\text { (median } \\
\text { (range) })\end{array}$ & p Value \\
\hline GST & $4 \cdot 7$ & 3.3 & $0.002^{\star}$ \\
(U/g Hb) & $(3.6-6.6)$ & $(2 \cdot 8-5 \cdot 3)$ & $0.02 \star$ \\
GSH & 0.93 & 0.82 & \\
$(\mathrm{mM})$ & $(0.90-0.97)$ & $(0.73-0.86)$ & \\
\hline
\end{tabular}

^Statistically significant $(p<0.05)$. 


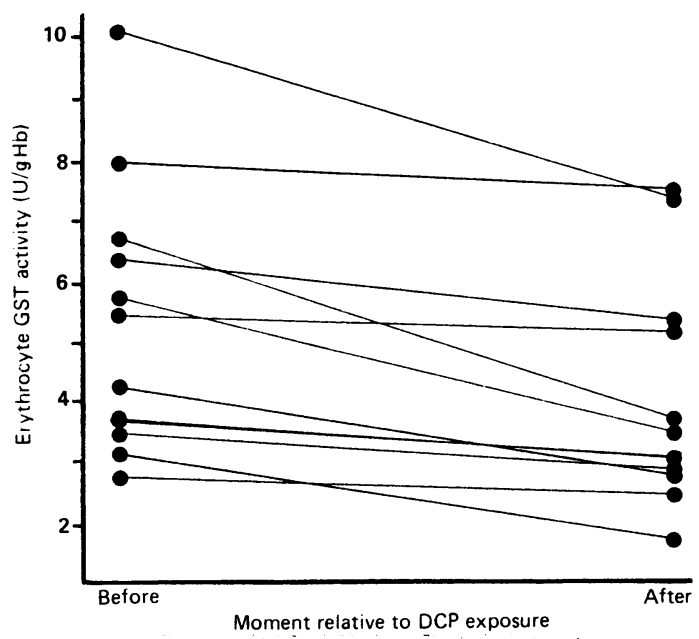

Figure 1 Glutathione S-transferase activity in erythrocytes measured before and after the season.

\section{LIVER FUNCTION}

With the exception of Bil-tot no significant differences were found for the parameters of liver function between samples obtained before and after the season (table 1). Concentration of Bil-tot was significantly decreased after the season from 9.5 to $7 \cdot 0 \mu \mathrm{mol} / \mathrm{l}$ (median values; $\mathrm{p}=0.025$ ). Activity of GGT was appreciably increased from 12.5 before to $19 \cdot 5 \mathrm{U} / 1$ after the season but the difference was only of borderline significance (median values; $\mathrm{p}=0.099$ ).

\section{RENAL FUNCTION}

For two out of three glomerular function parameters, Creat-S and Alb-U, significant differences between the concentrations before and after the season were found. Concentration of Creat-S decreased from

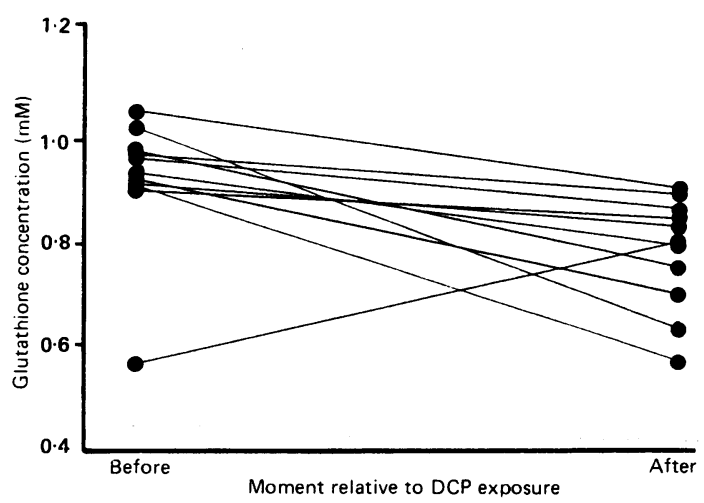

Figure 2 Glutathione concentration in blood measured before and after the season.
93.0 to $87.5 \mu \mathrm{mol} / 1$ (median values; $\mathrm{p}=0.013$ ) (table 2 ). In one subject, however, Creat-S was very low especially at the end of the season. This person had been treated with ampicillin one month before the study. Concentration of $\mathrm{Alb}-\mathrm{U}$ increased from $5 \cdot 2$ to $7.6 \mathrm{mg} / \mathrm{l}$ (median values; $\mathrm{p}=0.044$ ) (table 2 ). The excretion of albumin in urine is normally less than $8 \mathrm{mg} / \mathrm{l}^{16}$ One applicator had values three times higher than this value, before as well as after the season. This person was advised to consult his general practitioner.

The only tubular function parameter that was significantly increased after the season was RBP, from 20.0 to $26.9 \mu \mathrm{g} / \mathrm{l}$ (median values; $\mathrm{p}=0.036$ ). No significant differences were found for $\beta_{2}-\mathrm{M}$ concentrations in urine or in serum, and for AAP and $\beta$-Gal activities in urine (table 2 ).

The concentration of $\beta_{2}-\mathrm{M}$ in urine is normally $200 \mu \mathrm{g} / 1 .{ }^{16}$ Three workers had values above this value but below $300 \mu \mathrm{g} / \mathrm{l}$, which is the normal upper limit according to the manufacturer of the assay kit. A significant difference was found by testing the differences between values before and after the season for all three glomerular function parameters together (median values; $p=0.011$, Friedman test). Statistical analyses of the data not adjusted for urinary density did not show significant differences in any renal function parameters under study.

\section{BLOOD GST AND GSH}

The concentration of GSH in blood decreased significantly from 0.93 before to $0.82 \mathrm{mM}$ after the season (table 3 , median values; $p=0.023$ ). The median GST activity decreased from 4.7 to $3.3 \mathrm{U} / \mathrm{g}$ $\mathrm{Hb}$ (median values; $\mathrm{p}=0.002$ ). The GSH concentrations were lowered after the season in all but one person, whereas GST activity was decreased in all persons (figures 1 and 2).

Lymphocytes from the same blood samples were tested for the presence of GST $\mu$ (RME Vos, RTH van Welie, WHM Peters, et al. Unpublished method). The GST activity in erythrocytes and GSH concentrations in blood were not significantly different for the positive and negative $\mu$ groups.

\section{Discussion}

Monitoring in occupational toxicology is directed towards the assessment of exposure, which may lead to minimisation of hazards or towards determination of early health effects, which may serve the added purpose of better risk evaluations. ${ }^{717}$ The liver and kidney function tests used in this study give information on the functional state of the organs concerned. Changes in GSH and GST may indicate primary biological effects. These cannot be interpreted, as yet, in terms of health effects, but only in terms of 
endogeneous exposure to electrophilic agents. The renal function tests used in this study are considered to be sensitive enough to detect early effects of nephrotoxins and are feasible as indicators of early changes in renal function. ${ }^{18}$ Low molecular weight proteins, such as $\beta_{2}-\mathrm{M}-\mathrm{U}$ and RBP, are freely filtered from the plasma by the renal glomerulus and reabsorbed by the proximal tubular cells. The reabsorption of these proteins by the kidney is almost complete, which explains why their presence in urine is a sensitive indicator of impaired proximal tubular function. ${ }^{18}$ In this study a significant increase of Alb$\mathrm{U}$ and $\mathrm{RBP}$ in urine was found after the season. If the increase in Alb- $U$ excretion can be attributed to reduction in tubular reabsorption, a much larger increase in RBP excretion would be expected. ${ }^{18}$ Both for Alb-U and RBP the excretion in urine was, however, low compared with other studies. ${ }^{11}$

No significant increase in $\beta_{2}-\mathrm{M}-\mathrm{U}$ was found, by contrast with what might be expected from another study in which a high correlation between RBP and $\beta_{2}-M-U$ was shown. ${ }^{8}$ This may be explained by the small amount of data on $\beta_{2}-M-U$ that could be used in our calculations. Data from eight out of 28 urine samples had to be excluded from the analysis because of a pH less than $5.5 ; \beta_{2}-\mathrm{M}-\mathrm{U}$ in acid urine is very unstable and the protein degrades quickly.

Increased excretion of high molecular weight proteins such as albumin and ferritin may also result from a reduced tubular reabsorption of the filtered load. ${ }^{18}$ An increased excretion of both a high (Alb-U) and a low (RBP) molecular weight protein may indicate a reduced tubular reabsorption capacity in these workers. Effects on the proximal tubules can also be detected by measuring the activity of several enzymes in the urine.$^{18}$ Neither of the two urinary enzymes measured in this study, AAP and $\beta$-Gal, had significantly increased activities after exposure to DCP during the season. After the present study was completed Osterloh et $a l^{4}$ described a subclinical effect on renal function expressed in an increased urinary excretion of $\mathrm{N}$-acetyl-glucosamidase after short term exposure to DCP through soil fumigation. The concentrations exposed to ranged from 0.26 to $9.36 \mathrm{mg} / \mathrm{m}^{3}$.

The exposure concentrations measured in our corresponding environmental monitoring study ranged from 1.9 to $18.9 \mathrm{mg} / \mathrm{m}^{3}$, and are comparable with those used in the animal studies in which a cloudy swelling of the renal tubular epithelium of male rats was found at $3 \mathrm{ppm}\left(13.6 \mathrm{mg} / \mathrm{m}^{3}\right)$ after six months of exposure. ${ }^{1}$ With regard to liver function, a significant decrease in concentration of Bil-tot in serum within the normal range was found after the season. Together with the remarkable increase in GGT this may indicate that DCP has enzyme-inducing properties. Induction of the $\beta$-glucuronidase activity may result in an increased contribution of conjugated Bil- tot, and hence in an increased elimination. In animal studies an effect on the liver was also found at a comparable exposure level; in female rats exposed for six months to $3 \mathrm{ppm}\left(13.6 \mathrm{mg} / \mathrm{m}^{3}\right)$ a higher liver to body weight ratio was found. No histopathological changes in the liver were seen, however, and the increase was considered not to be an adverse effect, although it may be related to exposure. ${ }^{1}$ Because the data from the present study were not compared with a control group the results might be influenced by seasonal variation. When the results were compared, however, with those of a study by Gidlow et al ${ }^{19}$ about seasonal fluctuations of some biochemical parameters monitored in industrial workers in the United Kingdom exposed to a variety of potentially toxic chemicals, it appeared that our results (a decrease in creat-S and an increase in GGT) were opposite to those expected from seasonal fluctuations. Because of the electrophilic nature of DCP attack on sulfhydryl groups can be expected. Glutathione provides the largest pool of biologically available thiol groups. Normal GSH concentrations in blood do not differ much between people of the same age group. ${ }^{20}$

The in vitro susceptibility of erythrocyte GST activity to industrially important electrophilic agents has been described. ${ }^{21} \mathrm{~A}$ decrease of GST activity upon occupational exposure to hot rubber fumes has been reported..$^{22}$ The authors expected to find induction of GST synthesis, which in that case could occur during the proliferation of erythrocytes. In a separate study we found that such an induction does take place in smokers as GST concentrations determined by ELISA increased, whereas the activity towards CDNB was not increased (CTA Evelo, PTh Henderson, JGP Peters, GJ Reijmer, RP Bos. Unpublished observations). In the current exposure situation a decrease in activity due to inactivation of GST is expected to prevail over induction because the duration of the exposure period was short compared with the life span of an erythrocyte.

Normal GST activity shows appreciable variation between subjects. ${ }^{23}$ In this respect the comparison of individual pre- and post-exposure values is expected to be more sensitive than comparison with a control group. Until now, no genetic inhomogeneity has been found to explain the interindividual variations in erythrocyte GST activity towards CDNB (mainly GST activity). Such genetic differences are known to exist for GST $\mu^{24}$ and are expected for the minor erythrocyte GST. ${ }^{25}$ Therefore, the absence of a relation between erythrocyte GST and the presence or absence of GST $\mu$ in lymphocytes was not surprising. The distinct decrease of both GSH and GST values found in this study indicates that exposure to DCP has affected glutathione conjugating capacity.

We wish to thank A J Moolenaar, J H M Souverijn, 
$M$ A Verschoor, A $M$ van Schijndel, $H$ du Jour, and G J Reijmer for their analytical support and D $\mathbf{H}$ Brouwer, J J van Hemmen, R P Bos, P Th Henderson, and $\mathrm{R} L \mathrm{Zielhuis}$ for their valuable comments on the manuscript.

This study was financially supported by the Food and Allied Workers Union.

Requests for reprints to: F A de Wolff, Toxicology Laboratory, University Hospital, Building 1, L1-P, PO Box 9600, 2300 RC Leiden, The Netherlands.

1 Torkelson TR, Oyen F. The toxicity of 1,3-dichloropropene as determined by repeated exposure of laboratory animals. Am Ind Hyg Assoc J 1977;38:217-23.

2 Albrecht NA. Toxicology and hazard assessment of 1,3dichloropropene (Telone II). Arch Environ Health 1987; 42:292-6.

3 Ministry of Social Affairs and Workforce, Directorate General of Labour. Nationale MAC-list. (in Dutch.) Voorburg. 1989.

4 Osterloh JD, Wang R, Schneider S, Maddy K. Biological monitoring of dichloropropene: air concentrations, urinary metabolite, and renal enzyme excretion. Arch Environ Health 1989;44:207-13.

5 Brouwer DH, Brouwer EJ, Vreede JAF de, Welie RTH van, Vermeulen NPE, Hemmen JJ van. Inhalation exposure to 1,3dichloropropene in the Dutch flower bulb culture. Part I. Environmental monitoring. Arch Environ Contam Toxicol (in press).

6 Welie RTH van, Duyn P van, Brouwer DH, Hemmen JJ van, Brouwer EJ, Vermeulen NPE. Inhalation exposure to 1,3dichloropropene in the Dutch flower bulb culture. Part II. Biological monitoring by measurement of urinary excretion of two mercapturic acid metabolites. Arch Environ Contam Toxicol (in press).

7 Henderson RF, Bechtold WE, Bond JA, Sun JD. The use of biological markers in toxicology. CRC Crit Rev Toxicol 1989;20:65-82.

8 Bernard AM, Lauwerys RR. Latex immunoassay of urinary albumin. J Clin Chem Clin Biochem 1983;21:25-30.
9 Maruhn D. Rapid colorimetric assay of $\beta$-galactosidase and Nacetyl- $\beta$-glucosaminidase in human urine. Clin Chim Acta 1976;73:453-61.

10 Jung K, Scholz D. An optimized assay of alanine aminopeptidase activity in urine. Clin Chem 1980;26:1251-4.

11 Verschoor MA. Occupational exposure to metals and renal function. Rodopi, Amsterdam: 1987. (PhD thesis.)

12 Anderson ME. Determination of glutathione and glutathione disulfide in biological samples. Methods Enzymol 1985;113:548-55.

13 Habig WH, Jacoby WB. Assays for the differentiation of glutathione S-transferase. Methods Enzymol 1981;77: 398-405.

14 Kampen EJ van, Zijlstra WG. Determination of hemoglobin and its derivatives. Adv Clin Chem 1965;8:141-87.

15 Norusis MJ. SPSS lect. Chicago, Ill: SPSS Inc., 1986.

16 Roels H, Lauwerys R. Early detection of nephrotoxic effects of industrial chemicals. Umwelthygiëne 1984;(suppl 1):217-44.

17 Zielhuis RL, Henderson PTh. Definitions of monitoring activities and their relevance for the practice of occupational Health. Int Arch Occup Environ Health 1986;57:249-57.

18 Lauwerys RR, Bernard A. Early detection of the nephrotoxic effects of industrial chemicals: state of the art and future prospect. Am J Ind Med 1987;11:275-85.

19 Gidlow DA, Church JF, Clayton BE. Haematological and biochemical parameters in an industrial workforce. Ann Clin Biochem 1983;20:341-8.

20 Al-Turk WA, Stohs SJ, El-Rashidy FH, Othman S. Changes in glutathione and its metabolizing enzymes in human erythrocytes and lymphocytes with age. J Pharm Pharmacol 1987;39:13-6.

21 Ansari GAS, Singh SV, Gan JC, Awasthi YC. Human erythrocyte glutathione S-transferase: a possible marker of chemical exposure. Toxicol Lett 1987;37:57-62.

22 Kilpikari I, Savolainen $H$. Decreased erythrocyte glutathione Stransferase activity in rubber workers. Int Arch Occup Environ Health 1984;53:299-302.

23 Strange RC, Johnson PH, Lawton A, et al. Studies on the variability of glutathione S-transferase from human erythrocytes. Clin Chim Acta 1982;120:251-60.

24 Warholm M, Guthenberg C, Mannervik B. Molecular and catalytic properties of glutathione transferase $\mu$ from human liver: an enzyme efficiently conjugating epoxides. Biochemistry 1983;22:3610-27.

25 Peter H, Deutschman S, Reichel C, Hallier E. Metabolism of methyl chloride by human erythrocytes. Arch Toxicol 1989;63:351-5.

Accepted 3 September 1990 


\section{CORRESPONDENCE}

\section{Employment in pulp mills as a possible risk factor for soft tissue sarcoma: a case report}

Sir,- A 60 year old man was admitted to our department in 1989 with a soft tissue sarcoma (malignancy grade III) of the neurofibrosarcoma type located in the heart. He had been employed in sulphate pulp mills since 1951 and since 1970 he supervised the drainage of the sludge from the whole mill. He was thus in skin contact with both the sludge and the drainage water. The mill used chlorine bleaching.

In four case-control studies we have associated soft tissue sarcoma with exposure to chlorinated phenols, ${ }^{1-4}$ a finding also reported in other studies as discussed in our latest report. ${ }^{4} \mathrm{We}$ have recently attributed the increased risk to dioxin contaminated phenoxyacetic acids or chlorophenols. ${ }^{4}$ Furthermore dioxins are carcinogenic in animal experiments. ${ }^{56}$ In several studies it has been clearly shown that dioxins are produced in the chlorine bleaching process of the pulp, and that the concentrations are directly related to the amount of chlorine used in the bleaching process. ${ }^{7}$ Dioxins appear to be concentrated in pulp mill sludges and in sediments outside pulp mills creating a long term exposure situation for affected areas. ${ }^{7}$ This might be a source of exposure to dioxin for employees in the pulp industry and thus of aetiological significance for our patient described above. We are currently investigating this possible association further.

MIKAEL ERIKSSON LENNART HARDELL Department of Oncology, University Hospital, S-901 85 Umed, Sweden

1 Hardell L, Sandström A. A case-control study: soft-tissue sarcomas and exposure to phenoxyacetic acids or chlorophenols. $\mathrm{Br} J$ Cancer 1979; 39:711-7.

2 Eriksson M, Hardell L, Berg NO, et al. Soft-tissue sarcomas and exposure to chemical substances: a case-referent study. Br J Ind Med 1981;38:27-33.

3 Hardell L, Eriksson M. The association between soft tissue sarcomas and exposure to phenoxyacetic acids. A new case-referent study. Cancer 1988; 62:652-6.
4 Eriksson M, Hardell L, Adami H-O. Exposure to dioxins as a risk factor for soft tissue sarcoma: a populationbased case-control study. J Natl Cancer Inst 1990;82:486-90.

5 Kociba RJ, Keyes DG, Beyer JE, et al. Results of a two-year chronic toxicity and oncogenicity study of $2,3,7,8-$ tetrachloro-dibenzo-p-dioxin in rats. Toxicol Appl Pharmacol 1978;46: 279-303.

6 National Toxicology Program, National Cancer Institute. NIH bioassay of a mixture of $1,2,3,6,7,8$ and $1,2,3,7,8,9-$ hexachloro dibenzo-p-dioxins for carcinogenicity (gavage study). Research Triangle Park, NC: DHHS, 1980. (NTP tech rep ser No 198; DHHS publ No (NIH) 80-198.)

7. Swanson SE. Dioxins in the bleach plant. Umeả, Sweden: Umeå University 1988. (Dissertation.)

NOTICE

Fourth Summer Institute in Environmental Health Studies, Baltimore MD, 3-14 June 1991.

The Fourth Summer Institute in Environmental Health Studies will present courses during a two week period for academic credit or for continuing education credit. It will be possible to register for more than one course. The Summer Institute is designed for the following groups: (1) people unable to take the traditional four quarters of graduate study leading to a degree, (2) practising health professionals-that is, physicians, nurses, industrial hygienists, toxicologists, and safety engineers, (3) men and women with responsibility for health, safety, and environmental matters in either government service or the corporate world, (4) public health practitioners. Subjects will include: principles of toxicology, risk communication of environmental hazards, fundamentals of occupational health, physical agents in environmental health sciences, contemporary problems in radiation health sciences, risk assessment and risk management, and case studies and principles of industrial hygiene. For further information contact $\mathrm{Dr}$ Jacqueline Corn, Director, Continuing Education Program or Catherine Walsh, Course Coordinator, Depart- ment of Environmental Health Sciences, The Johns Hopkins University School of Hygiene and Public Health, 615 North Wolfe Street, Room 6001, Baltimore, Maryland 21205, USA.

\section{Correction}

Biological effect monitoring of occupational exposure to 1,3dichloropropane: effects on liver and renal function and on glutathione conjugation $(1991 ; 48$ (March):167-72).

In the fourth line of the second column of the abstract "... creatinine excretion" should read ". . . creatinine concentration." 